\title{
BERKETUHANAN DALAM PERSPEKTIF KEPERCAYAAN SUNDA WIWITAN
}

\author{
Ira Indrawardana
}

\author{
| Postgraduate Student \\ Padjadjaran University \\ Bandung, Indonesia
}

\begin{abstract}
:
By referring to the variety of cultures that have emerged and flourished in Indonesia, the author wants to figure the depth of 'belief' in God in relation to the respective cultural and spiritual expressions and through the rituals performed by the people of this belief (kepercayaan). Because of the influence of 'Western' beliefs brought into Indonesia by the colonialists in the past, the life of the people believing in God from within their own local beliefs together with the diversity of their cultures and spiritualities seem to have been marginalised. What is needed is a sort of new paradigm to view and value the local beliefs in the face of the so-called 'official religions' in Indonesia. This greater appreciation to the people of the local beliefs is in the line with the growing awareness of plurality of societies in this land. Efforts to recognise and understand the essence and values in the system of the local belief are of great importance. The author tries to explore how the doctrines of the belief Sunda Wiwitan develop by starting to browse the historical aspect of Manusia Sunda ('Sundanese human being') within its religious context and the other related elements in this system of belief. What is most important for the adherents of Sunda Wiwitan is not so much the frequence of praying to or worshiping God as the effort of every individual to maintain the attitude and deeds as a human being that keep the harmony of relation with the other human beings, the surrounding nature with all its contents, and God.
\end{abstract}

Keywords: local belief $\bullet$ religion $\bullet$ culture $\bullet$ Sunda Wiwitan - Sundanese buman being $\bullet$ history of local belief $\boldsymbol{\bullet}$ religiosity $\boldsymbol{\bullet}$ social recognition 


\section{Introduksi}

Indonesia adalah satu bangsa untuk semua suku bangsa dan bangsa yang ada dan hidup di Bumi Nusantara. Semua suku bangsa memiliki kebebasan berkebudayaan demi kemajuan Indonesia yang dimiliki bersama itu. Aspek berkebudayaan di dalamnya mengandung aspek religius atau aspek berkepercayaan terhadap "Tuhan" yang diyakininya. Kalaulah merujuk pada keanekaragaman kebudayaan yang tumbuh dan berkembang di Nusantara, kita akan melihat keanekaragaman kepercayaan kepada Tuhan dengan berbagai ekpresi budaya spiritual dan dalam berbagai ritual yang dilakukannya. Semua bentuk kehidupan berkepercayaan itu dijadikan landasan bersama sebagai bangsa Indonesia dalam kerangka sistem nilai kepercayaan bersama terhadap Tuhan Yang Maha Esa.

Berdasarkan kajian antropologi, Indonesia terdiri atas lebih dari 500 suku dan subsuku bangsa dengan ciri-ciri bahasa dan kebudayaan tersendiri. Setiap suku bangsa dan subsuku bangsa di Indonesia dapat dikatakan mempunyai satu daerah asal, pengalaman sejarah, dan nenek moyang. Suku bangsa atau etnis adalah golongan sosial yang memiliki ciri-ciri tersendiri berdasarkan karakter budaya etnisnya dan cenderung dipertahankan keberadaan budaya mereka, secara khusus oleh pada pendukung etnis tersebut. Gambaran saling mempertahankan keberadaan ciri-ciri budaya etnis ini begitu indah terlukiskan dan hidup di sepanjang bentangan pulau-pulau di Nusantara, sehingga para pendiri bangsa ini memberikan motto kepada bangsa Indonesia: Bhinneka Tunggal Ika.

\section{Agama dan Kepercayaan}

Patut disayangkan, karena seolah-olah sudah menjadi kewajaran, kebhinekaan suku bangsa-suku bangsa di Indonesia dipinggirkan oleh sebentuk "rezim budaya dunia" yang dikenal dengan 'globalisasi' dan 'modernisasi'. Dampak "rezim budaya dunia" itu sedemikian rupa merasuk ke dalam tatanan kehidupan bangsa ini melalui berbagai media sosial, institusi, jaringan sosial, politik dan pranata-paranata sosial budaya masyarakat, yang secara langsung atau tidak langsung dirasakan oleh masyarakat Indonesia. Kondisi ini dalam perspektif antropologis nampak sebagai 'dinamika' kebudayaan yang tidak bisa ditawar-tawar lagi, terutama dalam konteks saling-silang budaya dari hubungan antarbangsa di dunia. Kondisi ini di antaranya didorong oleh gerakan modernisme di Barat yang 
mendorong bangsa Barat untuk menemukan 'dunia baru' di berbagai belahan dunia, bahkan dengan cara menjajah wilayah yang mereka kunjungi. Penjajahan yang dimaksud bukan sekedar penjajahan ekonomi, tetapi lebih luas lagi merupakan penjajahan budaya, di antaranya nampak dalam semangat mencari 'emas', kemenangan, dan ajaran agama Barat (Agus, 2006).

Dampak dari kondisi silang budaya ini adalah bahwa kehidupan berkeyakinan atau berkepercayaan kepada Tuhan Yang Maha Esa dalam keragaman budaya spiritual pun mengalami marginalisasi. Beberapa aliran kepercayaan terpinggirkan, bahkan terjadi etnifikasi atau peminggiran etnik lokal oleh pendatang dalam beberapa kasus di Indonesia. Etnik lokal menjadi "komunitas minor" dalam praktik kebudayaannya di lingkungannya sendiri. Contohnya adalah apa yang terjadi pada masyarakat etnik Lampung (dalam kajian Irianto dkk., 2011) atau kasus peminggiran penganut kepercayaan adat Sunda Wiwitan masyarakat Kanekes (Baduy) dan AKUR (Adat Karuhun Urang), Cigugur, yang penganutnya tersebar di Jawa Barat, dan lain-lain. Oleh karenanya, menurut Anas Saidi (2004) pujian terhadap Indonesia yang merupakan pertemuan agama-agama besar dunia (Islam, Katolik, Kristen Protestan, Hindu, dan Budha) yang hidup secara berdampingan, yang dianggap berhasil meredakan konflik keagamaan (tanpa membawa kepada disintegrasi bangsa), kini benar-benar mendapatkan ujian yang paling berat.

Dalam kenyataan, menurut Anas Saidi (2004), agama telah menjadi identitas inheren dalam kehidupan berbangsa. Tiada kebakuan prediksi yang mampu melayani pertanyaan-pertanyaan (1) kapan agama akan menempati posisi sebagai faktor perekat, (2) kapan pula menjadi faktor pemecah, serta (3) elemen-elemen apa saja yang harus direduksi ketika agama menjadi sumber ketegangan. Hal tersebut membuat banyak kalangan mengalami kebingungan untuk memahami dan menyelesaikan konflik sosial yang bernuansa 'agama', yang terus-menerus menjadi ancaman integrasi bangsa. Pandangan yang terakhir tadi memberikan gambaran bahwa posisi agama sebagai bagian dari ikatan primordial telah memiliki karakteristik yang berbeda jika dibandingkan dengan ikatan primordial lainnya. Sebagai masalah ultim (pokok dan terakhir), setiap agama telah memiliki doktrin kemutlakan kebenaran yang memiliki konsekuensi logis untuk menafikan kebenaran agama lain. Doktrin 'keagamaan' semacam 
ini makin mempersulit lahirnya paradigma pluralis yang percaya bahwa setiap agama memiliki jalan keselamatannya sendiri. Doktrin keagamaan yang cenderung memaksa bagi kaum adat ini juga disebabkan adanya dikotomi konseptual antara istilah agama dan kepercayaan. Sejauh ini hal tersebut masih menjadi perdebatan cukup panjang di antara kelompok yang menganggap bahwa istilah agama adalah bagi keyakinan yang "resmi diakui negara" (yang datang dari luar dan disebarkan di Indonesia), sedangkan keyakinan adat bukanlah agama tetapi 'kepercayaan'.

Oleh karena itu, diperlukan suatu 'paradigma baru' dalam cara pandang dan sikap di hadapan kepercayaan atau agama lain dengan diri sendiri dalam kehidupan masyarakat yang heterogen di Indonesia. Misalnya, diperlukan usaha mengenal dan memahami esensi dan nilainilai sistem kepercayaan yang lain. Mengapa demikian? Metafornya ialah hubungan pertemanan dan persaudaraan. Kalau tidak mengenal, tidak akan muncul sikap empati dan persaudaraan. Mengenal sesuatu, bukan berarti untuk menjadi sesuatu itu, tetapi menghadirkan sesuatu itu bagian dari lingkungan hidup kita, atau kita menjadi bagian dari lingkungan hidup sesuatu itu dalam suasana persaudaraan dan kebersamaan. Dalam konteks inilah tema tulisan ini dieksplorasi untuk mengenalkan secara sekilas bagaimana kehidupan berkeyakinan atau berkepercayaan kepada Tuhan Yang Maha Esa di sekitar kita. Kepercayaan yang akan kita bahas itu ada di dalam masyarakat Indonesia, yang keberadaanya sudah ada jauh sebelum keberadaan negara dan bangsa Indonesia, yaitu sistem, tatanan nilai, dan faham sosial ajaran Sunda Wiwitan.

\section{Sunda Wiwitan dan Religusitas Manusia Sunda}

Kita akan mencoba memahami apa dan bagaimana berkembangnya ajaran Sunda Wiwitan, mulai dengan menelusuri sekilas aspek historis 'manusia Sunda' dalam konteks religiusitas dan hal-hal yang terkait dengan unsur dan sistem kepercayaannya. Berangkat dari asumsi dasar bahwa Tuhan Semesta Alam ini (dengan berbagai sebutan dan cara bersembahyang dari berbagai sistem kepercayaan di dunia) telah menciptakan manusia dengan bangsa-bangsanya, dan di antaranya adalah manusia yang hidup dengan dan mencirikan kebudayaan Sunda. Dilihat dari peristilahannya, kata 'Sunda' telah dikenal sejak lama baik dalam peta dunia (geografis) maupun budaya dunia (filosofis). Adapun dalam aspek kesukubangsaan, istilah 
Sunda mengacu pada posisi dan rasa kesukubangsaan yang dinegasikan dengan posisi dan rasa kebangsaan setelah Republik Indonesia berdiri.

'Sunda Wiwitan' terdiri atas dua kata: Sunda dan Wiwitan. Istilah 'Sunda' (menurut P. Djatikusumah) dimaknai dalam tiga kategori konseptual dasar, yaitu: (1) filosofis: Sunda berarti bodas (putih), bersih, cahaya, indah, bagus, cantik, baik dan seterusnya; (2) etnis: Sunda berarti atau merujuk pada komunitas masyarakat suku bangsa Sunda yang Tuhan ciptakan seperti halnya suku dan bangsa lain di muka bumi. Dalam hal ini berkaitan dengan kebudayaan Sunda yang melekat pada cara dan ciri manusia Sunda; (3) geografis: Sunda berarti mengacu sebagai penamaan suatu wilayah berdasarkan peta dunia sejak masa lalu terhadap wilayah Indonesia (Nusantara), yaitu sebagai tataran wilayah 'Sunda Besar' (The Greater Sunda Islands) meliputi himpunan pulau yang berukuran besar (Sumatera, Jawa, Madura, Kalimantan) dan 'Sunda Kecil' (The Lesser Sunda Islands), yaitu deretan pulau yang berukuran lebih kecil dan terletak di sebelah timur Pulau Jawa (Bali, Lombok, Flores, Sumbawa, Sumba, Roti, dan lain-lain).

Keberadaan "manusia Sunda" masa lalu di antaranya bisa dilihat pada peninggalan-peninggalan. Mengacu pada temuan artefak yang berumur ribuan bahkan puluhan ribu tahun sebelum masehi di dataran tinggi Bandung (sebagai wilayah cekungan Bandung), benda-benda tersebut adalah salah satu bukti penulusuran leluhur "Ki Sunda" (Koesoemadinata, dalam Rosidi dkk., 2006). Adanya situs-situs purbakala tertentu, misalnya, situs purbakala Cipari, Kuningan, yang ditaksir berusia 2000-3000 tahun SM, menunjukkan bahwa "manusia Sunda" sudah mengenal tatanan hidup bermasyarakat dengan sistem kepercayaan atau religiositasnya. Menurut tafsir arkeologi adanya situs artefak menhir dan lingga yoni di Cipari adalah bukti nenek moyang bangsa Indonesia (khususnya nenek moyang manusia Sunda) sudah memiliki karakter dan sifat religius.

Berdasarkan data arkeologis, di wilayah Jawa Barat dan Banten (yang nota bene dominan hidup masyarakat suku bangsa Sunda/orang Sunda) telah ditemukan berbagai artefak arkeologi seperti situs megalitikum Gunung Padang di Kabupaten Cianjur, situs masa transisi megalitikum ke neolotikum di Situs Cipari, Kabupaten Kuningan, Situs Sagarahiang di Kabupaten Kuningan, Situs Arca Domas di Kanekes, Kabupaten LebakBanten, dan sebagainya. Pada situs-situs prasejarah tersebut terdapat artefak yang menurut ahli arkeologi terkait dengan nilai-nilai religius masa 
prasejarah yaitu menhir, lingga dan yoni. Menhir adalah salah satu simbol penghormatan sekaligus tempat pemujaan terhadap leluhur dan atau "Yang Maha" dalam sistem kepercayaan Orang Sunda masa prasejarah. Lingga dan Yoni adalah lambang kesuburan, dan juga simbol kesadaran dalam sistem kepercayaan Orang Sunda masa lalu berkaitan dengan adanya ketentuan atau tangtu mengenai hukum alam adanya laki-laki dan perempuan, siang dan malam, dan sebagainya. Di dalam kehidupan terdapat papasangan atau 'ketentuan' yang saling berpasangan.

Upaya penelusuran jejak-jejak dinamika spiritual Orang Sunda masa lalu, sebagai upaya pengungkapan eksistensi kebudayaan Sunda berikut penjelasan sistem kepercayaan 'asli' masyarakat Sunda, terkadang mendapatkan reaksi yang kontraproduktif dari masyarakat Sunda sendiri. Sampai saat ini masih ada berbagai pendapat yang mengatakan bahwa kerajaan Sunda masa lalu, termasuk raja-rajanya, adalah penganut Hindu; ada pula yang berpendapat bukan Hindu, tetapi penganut Agama Asli Sunda atau sistem kepercayaan leluhur Sunda sebelum pengaruh Hindu masuk. Ada pula polemik atas klaim bahwa Orang Sunda itu sudah Islami sebelum agama Islam masuk, sehingga beranggapan bahwa Orang Sunda adalah penganut agama Islam. Munculnya komunitas kaum penghayat kepercayaan terhadap Tuhan Yang Maha Esa atau dahulu ada yang menyebutnya sebagai Aliran Kepercayaan atau Aliran Kebatinan dianggap sebagai kelompok yang 'menyimpang' dari "agama-agama samawi”. Karena anggapan itu, imbasnya ialah pernah ada pelarangan tradisi upacara adat agraris Sunda berupa syukuran hasil bumi/panen yang disebut dengan Upacara Adat Seren Taun.

Terlepas dari polemik yang masih berkembang sampai sekarang itu, adanya artefak peninggalan prasejarah maupun sejarah yang terkait dengan simbol dan ajaran yang tertulis dalam naskah-naskah kuno menyiratkan dan menyuratkan bahwa Orang Sunda sejak Zaman Prasejarah sudah bersifat religius, atau memiliki kepercayaan dan sistem kepercayaan terhadap Tuhan. Beberapa data mengungkapkan sebutan-sebutan terhadap yang disembah dan diyakini dalam sistem kepercayaan masyarakat Sunda masa lalu, seperti Hiang atau Hyang, Hyang Tunggal, Batara Tunggal, Nu Ngersakeun, Gusti Pangeran Sikang sawiji-wiji, dan sebagainya. Menurut Richadiana (2006: 264) Hyang sebagai istilah kuno yang umum sampai sekarang digunakan dalam penyebutan kepada Sang Maha Pencipta Alam Raya beserta isinya 
ini adalah unsur yang tanpa wujud atau supranatural. Ia tidak dapat dilihat dengan mata telanjang, tetapi melalui rasa yang telah atis ("bati peureu tinggal nu atis tina rasa" - perilaku tapa guna menghilangkan segala kotoran \{noda\} yang melekat pada fisik dan jiwa, layaknya melepas karat pada besi sehingga kian lama kian jernih dan bersih \{suci\} dan tiba pada hakikat kehiduan sejati). Wujud yang tertinggi itu dilambangkan dengan bentuk yang sesuai dengan kebutuhan, kepercayaan, dan kemampuan manusia itu sendiri (pendukung budaya).

Salah satu bukti bahwa di masa awal perkembangan kerajaankerajaan di Tatar Sunda masyarakat Sunda "pada masa itu" sudah menunjukkan sikap dan perilaku religius adalah apa yang tersirat dalam Carita Parabiyangan yang ditulis oleh Pangeran Wangsa Kerta (1680). Kisah ini bertutur tentang Kerajaan Saung Galah di Kuningan (daerah Kabupaten Kuningan) pada masa kepimpinan Rahiyangtang Kuku. Pengaruh Rahiyangtang Kuku yang begitu mendalam dan dihormati oleh kerajaan-kerajan di bawah pengaruh kekuasaannya disebabkan ia teguh dalam menjaga "amanat dan ajaran kabuyutan" atau leluhurnya yang disebut dengan Dangiang Kuning, dan dalam mempersatukan bbinneka budaya, adat dan kehormatan masing-masing kerajaan di bawah pengaruhnya itu. Bahkan Rahyang Sanjaya yang pada masa itu hendak menguasai wilayah Saung Galah, setelah mendapat petuah dari Sang Resi Guru dari Galunggung, mengungkapkan kekagumannya dan menghormati kekuasaan Rahiyangtang Kuku, serta tidak akan mengganggu ajaran leluhur yang diagem atau dipedomani serta diimani oleh Rahiyangtang Kuku. Selain itu, Sang Seuweukarma atau Rahiyangtang Kuku menegaskan keyakinannya terhadap ajaran leluhur atau pedoman 'agama' leluhur untuk menjaga kebhinekaan raja-raja yang berbakti kepadanya dan hal itu diutarakan kepada utusan Rahiyang Sanjaya. Isi dari pernyataan Rahiyangtang Kuku ialah sebagai berikut.

(XIII,19b. “...Pun Rahiyangtang Kuku tu meunang tapana. Mikuku(b) Sanghiyang Darma kalwan Sanghiyang Siksa. Nurut talata(b) Sang Rumubun, ngawayangkeun awak carita. Bo(b) keh ku urang turut tanpa tingtimana. Biyaktakeun ku urang. Ja urang sarwa kaputran. Urang deung tohaan pabi anak. dewata..."

Kata 'wiwitan' secara literal berarti 'asal mula', sedangkan 'Sunda Wiwitan' berarti Sunda asal atau Sunda asli (Danasamita et.al., 1986: 4-5). 
Menurut pengakuan dan kepercayaan orang Kanekes, leluhur mereka mempunyai hubungan langsung dengan Adam (manusia pertama) dan agama yang mereka anut disebut Sunda Wiwitan (Geise, 1952: 204; Danasasmita et.al, 1986: 75-106; Garna, 1988). Selanjutnya, Sunda Wiwitan juga sering dipakai sebagai penamaan atas keyakinan atau sistem keyakinan "masyarakat keturunan Sunda" yang masih mengukuhkan ajaran spiritual leluhur kesundaan. Penamaan itu tidak muncul serta merta sebagai sebuah konsep penamaan keyakinan oleh komunitas penganut Sunda Wiwitan, tetapi kemudian dilekatkan pada beberapa komunitas dan individu Sunda (orang Sunda) yang dengan kokoh mempertahankan budaya spiritual dan tuntunan ajaran leluhur Sunda.

Dengan demikian Sunda Wiwitan secara literal berarti Orang Etnis Sunda Awal atau awal mula orang Sunda. Sunda Wiwitan yang sejauh ini oleh para antropolog Indonesia dianggap sebagai salah satu sistem religi dan identitas masyarakat Sunda, khususnya di masyarakat Baduy atau Kanekes, dapat kita baca dalam perspektif masyarakat Kanekes sendiri. Berikut cuplikan wawancara dengan salah seorang warga Kanekes (sekitar tahun 2000) yang berasal dari Cikadu Pasir, daerah Puun Cikartawana ( tangtu Karatauan/kaprabuan).

"...Sunda Wiwitan teh mun ibaratna jaman baheula mah nya hartina Sunda mimiti. Pertamana aya urang sunda teh nyaeta nerjemabkeun nyaeta Sunda Wiwitan. Nu matak diayakeun KTP. Memang baheulana mah nu kasebut ngabaratapakeun nusa telu puluh telu bangawan sawidak lima, pancer salawe nagara teh pikeun ngasub ratu ngajayak menak, euweuh agama baheula mah, kitu ceuk kolot mah. Ngan kulantaran ayeuna mah jalma geus loba, diayakeun cenah kudu ngabogaan KTP. Nyaeta dibere titah ti baris kolot nyieun ngaran agama nyaeta Sunda Wiwitan. Ari pagaweanana Sunda Wiwitan lamun hayang nyaho atawa kurang natrat, pagawean Sunda Wiwitan eta nyaeta nu telu pulub telu nagara sawidak lima, pancer salawe nagara, eta bagianana, nyaeta ngukus,ngawalu, muja, ngalaksa, kalanjakan, kapundayan, ngabersihan Sasaka Domas. Pikeun nulung kanu butuh nalang kanu susah, nganteur anu sieun, mere kanu weleh, ngobor kanu poek eta bagianana. Nyokona anu saciduh metu saucap nyata di lingkungan daerah Baduy. Nu matak masalah ka kiri ka kananna mah kami moal daek nerangkeun ku sabab, ka hiji bisi salah jalan, kaduana bisi urangna kurang mapay. Ngan aya basa cenah mun cara eta tea mah basa singkatan, lojorna bae teu bisa dipotong, pendekna bae teu bisa disambung. Ari geus kitu mah kitu bae ti meletuk sampe ka meletek di lingkungan daerah Baduy mah moal aya perobahan kitu bae dina masalab bukum adat..."

Dasar religi masyarakat Baduy dalam ajaran Sunda Wiwitan adalah kepercayaan yang bersifat monoteistis, penghormatan kepada roh nenek 
moyang, dan kepercayaan kepada satu kekuasaan yakni Sanghyang Keresa (Yang Maha Kuasa), yang disebut juga Batara Tunggal (Yang Maha Esa), Batara Jagat (Penguasa Alam), dan Batara Seda Niskala (Yang Maha Gaib), serta yang bersemayam di Buwana Nyungcung (Buana Atas). Orientasi, konsep, dan pengamalan keagamaan ditujukan kepada pikukuh (pedoman atau aturan) untuk menyejahterakan kehidupan di jagat mahpar (dunia ramai). Dalam dimensi sebagai manusia sakti, Batara Tunggal memiliki keturunan tujuh orang batara yang dikirimkan ke dunia melalui Kabuyutan (wilayah yang disakralkan dalam komunitas Baduy); "titik awal bumi" ialah Sasaka Pusaka Buana. Konsep buwana bagi orang Baduy berkaitan dengan titik awal perjalanan dan tempat akhir kehidupan. (Garna, 1994: 57).

Kusnaka (2005) berpendapat bahwa menurut orang Baduy kata wiwitan berasal dari kata wit-wit-an yang berarti 'pepohonan'. Mereka menganalogikan bahwa unsur-unsur tubuh manusia itu berasal dari pepohonan, dan semua itu bertumbuh menjadi besar atau dewasa. Sesungguhnya, di kalangan mereka ada anggapan bahwa Sunda Wiwitan merupakan 'asal usul' atau pangkal dari semua agama. Semua agama yang ada di dunia ini akan mencerminkan nilai-nilai dasar agama wiwitan, yang dalam istilah mereka katitipan wiwitan. Dasar etis "agama wiwitan" - Sunda Wiwitan - itu tercermin pada pandangan orang baduy dalam memelihara keseimbangan hubungan antara manusia dengan sesamanya, lingkungan alamnya, dan Tuhan.

\section{Sunda Wiwitan dalam Ragam Religiusitas Kini}

Bukti administratif warga sipil yang dianggap membedakan seseorang atau masyarakat etnis Sunda yang memeluk keyakinan Sunda Wiwitan dan non-Sunda Wiwitan (penganut agama umum seperti Islam, Kristen, dll.) ialah bahwa pada kolom agama di Kartu Tanpa Penduduk tidak tercantum agama semit atau agama yang datang dari 'luar' (negeri). Kondisi ini juga terjadi pada "agama-agama adat" Nusantara seperti parmalim, pelebegu, kaharingan, kejawen, aluk ta dolo, dsb. Hal ini berkaitan dengan UU Administrasi Kependudukan No. 23 tahun 2006. Berdasarkan UU tersebut dikenal istilah golongan "penghayat kepercayaan terhadap Tuhan Yang Maha Esa" yang dibedakan dari golongan sosial "penganut agama" versi pemerintah. Penghayat Kepercayaan adalah istilah singkat bagi kaum Penghayat Kepercayaan terhadap Tuhan Yang Maha Esa. 
Menurut Peraturan Pemerintah Republik Indonesia No. 37 tahun 2007 tentang Pelaksanaan Undang-Undang No. 23 tahun 2006 tentang Administrasi Kependudukan Bab I pasal 1 ayat 19 dikatakan, "Penghayat Kepercayaan terhadap Tuhan Yang Maha Esa, selanjutnya disebut penghayat kepercayaan, adalah setiap orang yang mengakui dan meyakini nilai-nilai penghayatan kepercayaan terhadap Tuhan Yang Maha Esa."

Kepercayaan terhadap Tuhan Yang Maha Esa berdasarkan peraturan tersebut di atas pada Bab I pasal 1 ayat 18 dijelaskan: "Kepercayaan terhadap Tuhan Yang Maha Esa adalah pernyataan dan pelaksanaan hubungan pribadi dengan Tuhan Yang Maha Esa berdasarkan keyakinan yang diwujudkan dengan perilaku ketaqwaan dan peribadatan terhadap Tuhan Yang Maha Esa serta pengalaman budi luhur yang ajarannya bersumber dari kearifan lokal bangsa Indonesia."

Dalam kosmologi sistem keyakinan Sunda Wiwitan dan dalam kaitan dengan pembagian pancen amanat leluhur Sunda, dikenal adanya konsep tapa di mandala dan tapa di nagara. Tapa di Mandala dalam pemahaman harafiah adalah perna dan tugas warga Sunda Wiwitan masyarakat Kenekes yang menjaga Kabuyutan peninggalan nenek moyang dengan cara menjaga keutuhan warisan dan amanat leluhur Sunda dengan cara tidak sedikitpun merubahnya. Sementara itu, konsep Tapa di Nagara memiliki pengertian peran dan tugas warga Sunda Wiwitan yang hidup di luar kewilayahan Kanekes tetapi sama dalam menjaga Kabuyutan, warisan amanat dan ajaran leluhur Sunda dengan cara mengikuti atau menyelaraskan dengan perkembangan zaman. Dalam kaitan dengan kedua konsep ini kesatuan masyarakat Adat Karuhun Urang (AKUR) Sunda Cigugur Kuningan termasuk dalam peran sosial budaya tapa di nagara. Hal ini disebabkan bahwa di samping secara teguh menganut budaya spiritual kasundaan (Sunda Wiwitan), warganya juga hidup mengikuti perkembangan sosial budaya masyarakat pada umumnya.

Richadiana (2006: 255) mengatakan bahwa menurut akal sehat kabuyutan sebagai bangunan suci khas Sunda baik secara fisik maupun nonfisik tentu dilatari gagasan (inti) yang melahirkan pengetahuan dalam memilih, menentukan, dan mendayagunakan lahan serta lingkungan sesuai dengan potensi sumber dayanya. Konsep pengetahuan tersebut, yang direpresentasikan dalam bentuk sarana pemujaan, seharusnya ditunjang oleh ciri yang juga khas Sunda. Istilah 'kabuyutan' sebetulnya 
dapat dikembalikan kepada kata dasarnya yakni 'buyut' atau '(p)uyut, artinya pancakaki yang setingkat pupunden, sesuatu yang paling dihormati, baik manusia, tempat, senjata (keris), pohon tua yang besar, maupun bendabenda peninggalan masa lampau, dan secara khusus bangunan-bangunan suci (Poerbatjaraka, 1992; Zoetmulder, 1982: 44 dalam Richadiana, 2006). Berdasarkan karya sastra Bujangga Manik, 'kabuyutan' dimuliakan sebgai timbang taraju segala persoalan manusia. Contohnya, Gunung Galunggung adalah kabuyutan Saunggalah, Gunung Gede (kabuyutan Pakwan Pajajaran). Saringendiyanti (1994) menjelaskan bahwa kabuyutan sebagai situs upacara masyarakat Sunda Kuno itu merupakan bidang lahan yang mengandung tinggalan arkeologi berupa bangunan suci, baik yang masih berdiri secara lengkap ataupun tidak lengkap, merupakan benda yang bergerak dan tidak bergerak.

Hubungan manusia dengan Tuhannya merupakan hubungan yang sangat privat. Terkait dengan hal ini dalam pandangan Agama atau ageman Sunda Wiwitan tidak pernah dan memang tidak dilakukan propaganda agama atau kepercayaan berupa syiar atau misi, karena paham Sunda Wiwitan bukanlah "agama misi”. Bahkan, sebenarnya tidak mudah orang mengaku atau memeluk keyakinan Sunda Wiwitan. Ajaran Sunda Wiwitan dianut dan berkembang hanya pada masyarakat Suku Sunda, dan dengan demikian sistem ritus serta bahasa yang digunakan pun menggunakan tatacara budaya dan bahasa Sunda. Para penganut Sunda Wiwitan umumnya menitikberatkan tuah (amal, perbuatan). Agama mereka (Sunda Wiwitan) menekankan apa yang harus dilakukan sebagai manusia, serta cenderung lebih tertutup dalam hal mempermasalahkan atau memperdebatkan pada "apa yang mereka percayai". Hal ini disebabkan di kalangan penganut Sunda Wiwitan, Yang Dipercayai (yang diimani) itu bukan untuk diperdebatkan, tetapi yang penting bagaimana melaksanakan pikukuh atau aturan kehidupan manusia berdasarkan pada aturan-aturan adat di masingmasing wewengkon-nya atau wilayahnya. Masyarakat Kenekes mendasarkan aturan pikukub itu pada Tri Tangtu (tata wilayah aturan berdasarkan wilayah ke-Rama-an, ke-Resi-an, ke-Ratu-an), sedangkan pada masyarakat Adat Karuhun Urang Sunda (AKUR) di Cigugur Kuningan, aturan pikukuh yang dimaksud dikenal dengan Pikukub Tilu.

Menurut komunitas AKUR Cigugur, Kuningan, yang dahulu dikenal sebagai penganut paham $A D S$ (Ajaran Djawa Sunda), yang juga 
mengusung paham Sunda Wiwitan, mereka mempercayai Tuhan sebagai Hyang Maha Tunggal atau Esa, tetapi dzat-nya ada di mana-mana, maha kuasa, maha adil, maha asih, maha murah, dan maha bijaksana. Tuhan dalam pandangan keyakinan Sunda Wiwitan AKUR Cigugur, Kuningan, adalah dzat yang menciptakan alam semesta beserta segala isinya. Tuhan tidak jauh, dan tidak dapat dipisahkan dari ciptaaanya, terutama dari manusia sebagai makhluk Tuhan yang paling sempurna. Karena memiliki rasa dan pikir yang melahirkan budi pekerti, manusia memiliki nilai-nilai moral serta nila-nilai religius. Secara khusus, penyebutan 'Tuhan' atau Hyang dalam komunitas Sunda Wiwitan AKUR ini adalah Gusti Sikang Sawiji-wiji. Wiji artinya inti, inti dari kelangsungan hidup serta kehidupan di dunia ini. Sebagai inti dari segala kehidupan, Ia dapat ditransformasikan menjadi daya atau energi yang sifatnya konkret. Tuhan ada dalam setiap yang ada, dan keesaan Tuhan ada dalam setiap ciptaannya (Qoyim, 2004: 152).

Bagi masyarakat penganut Sunda Wiwitan AKUR, dalam menghayati kepercayaan terhadap Tuhan yang maha Esa, manusia harus yakin dan merasakan bahwa kehidupan ini terwujud dari perpaduan serta jalinan antara segala ciptaan Tuhan sebagai pernyataan keagungan-Nya. Kuasa dan pancaran kasih Yang Maha Asih terwujud dalam kemurahanNya, saat segala cipta dan kehidupan diatur-Nya dengan masing-masing fugsinya (Pemaparan Budaya Spiritual AKUR, 2002).

Keberadaan para pengusung ajaran dan nilai-nilai Sunda Wiwitan, baik yang di Baduy ataupun AKUR Cigugur sebagai penganut penghayat kepercayaan terhadap Tuhan Yang Maha Esa, cenderung disikapi awam dengan membedakan mereka secara terpisah dari kelompok penganut "agama-agama pendatang". Bahkan, ada yang mengatakan bahwa masyarakat penghayat kepercayaan ini, karena merupakan tradisi lokal, tidak termasuk dalam kelompok agama, sehingga dicap tidak ber-Tuhan. Sementara itu, ada juga upaya yang ingin 'mengagamakan' para penghayat kepercayaan lokal terhadap Tuhan Yang Maha Esa ini (seperti sejarah pensyiaran dan misi di masa lalu).

\section{Simpulan}

Pengingkaran apalagi diskriminasi terhadap keyakinan atau kepercayaan yang hidup dan berkembang di Nusantara adalah sebentuk penolakan (sejarah) kemanusiaan bangsa Indonesia sendiri. Bisa dikatakan 
bahwa sikap yang menafikan dan mendiskriminasi individu atau masyarakat dalam berkepercayaan terhadap Tuhan yang diyakininya dengan segenap aspek ritual dan spritualnya adalah tidak berjiwa kebangsaan Indonesia.

Dengan demikian, perjuangan demi kebebasan berkeyakinan menunjukkan masih adanya kelompok yang 'terjajah' dalam hal berkeyakinan, baik penjajahan terhadap pribadi, bangsa maupun budaya yang ditujukan kepada Tuhan. Kebebasan berkeyakinan dalam konteks masa depan kebangsaan Indonesia dapat dirumuskan: (1) terciptanya keadaan bahwa kesadaran individu sebagai manusia dibangun dalam semangat peri kemanusiaan, dengan berbagai cara dan cirinya masingmasing; (2) tumbuhnya kesadaran berkebangsaan Indonesia yang diwarnai semangat Bhinneka Tunggal Ika dalam kaitan dengan kepercayaan kepada Tuhan Yang Maha Esa, sesuai budaya spiritual dan keyakinan masingmasing penganut; (3) kondisi berkeyakinan bagi setiap warga bangsa Indonesia yang saling memerdekakan keyakinan satu dengan lainnya, dengan tujuan mewujudkan kedamaian di Nusantara dan di dunia.

Pentingnya berketuhanan bagi masyarakat penganut Sunda Wiwitan bukanlah pada seringnya berdoa atau 'beribadah' menyembah Tuhan, melainkan pada menjaga sikap dan perbuatan sebagai manusia yang menjaga keseimbangan hubungan dengan sesama manusia, alam lingkungan beserta isinya, dan Tuhan. Bagi masyarakat ini, pengukuhan budaya bangsa (lokal/etnis) adalah juga wujud kesadaran berketuhanan, sebab di situ ada kesadaran berbudaya bangsa sendiri, yakni bukti "manusia Sunda Wiwitan" menjalankan "amanat ciptaan kudrat" dari Tuhan Sang Maha Pencipta.

\section{Bibliografi}

A Committee of The royal Anthropological Institute of Great Britain and Ireland (1954) Notes and Queries on Anthropology. Sixth edition. London: Routledge and Kegan Paul Ltd.

Bustanudin, Agus (2006) Agama dalam Kebidupan Manusia: Pengantar Antropologi Agama. Jakarta: PT. Grafindo Persada.

Dagun, Save M. (2006) Kamus Besar Ilmu Pengetabuan. Edisi kedua. Jakarta: Lembaga Pengkajian Kebudayaan Nusantara (LPKN). 
Garna, Judistira (1994) 'Masyarakat Tradisional Banten dan Upaya Pelestarian Nilai-Nilai Budaya', Makalah Seminar Puncak-Puncak Perkembangan Warisan Budaya Banten, Forum Ilmiah Festival Banten 1994. Serang, 28-29 Agustus 1994.

Indrawardana, Ira (2011) 'Sunda Wiwitan dalam Dinamika Zaman', Konferensi Internasional Budaya Sunda II. Bandung, Jawa Barat, 19-22 Desember.

(2014) 'Eksistensi Penghayat Kepercayaan dalam Menjaga

Nilai-Nilai Luhur Budaya Bangsa Berdasarkan Pancasila', Evaluasi Implementasi Peraturan Bersama Menteri Kebudayaan dan Pariwisata dan Menteri Dalam Negeri No.43 dan 41 Tabun 2009 tentang Pedoman Pelayanan Kepada Penghayat Kepercayaan Terhadap Tuban Yang Maha Esa. Bandung, Jawa Barat, 20-22 Februari.

Irianto, Sulistyowati \& Margaretha, Risma (2011) 'Piil Pesenggiri: Modal Budaya dan Strategi Identitas Ulun Lampung', Jurnal Makara Sosial Humaniora 15(2): 140-150.

Kartakusuma, Richadiana (2006) 'Situs (Kabuyutan) Kawali di Ciamis, Jawa Barat: Ajaran Sunda di dalam Tatanan Tradisi Megalitik', dalam Rosidi, Ajip dkk. (ed.) Prosiding Konferensi Internasional Budaya Sunda (KIBS) 2006. Jilid 1. Bandung: Yayasan Kebudayaan Rancage.

Kosoemadinata, R.P. (2006) 'Asal-Usul dan Prasejarah Ki Sunda', dalam Rosidi, Ajip dkk. (ed.) Prosiding Konferensi Internasional Budaya Sunda (KIBS) 2006. Jilid 1. Bandung: Yayasan Kebudayaan Rancage.

Qoyim, Ibnu (ed.) (2004) Religi Lokal \& Pandangan Hidup: Kajian tentang Masyarakat Penganut Religi Tolotang dan Patuntung, Sipelebegu (Permalim), Saminisme dan Agama Jawa Sunda. Jakarta: Pusat Penelitian Kemasyarakatan dan Kebudayaan. LIPI

Saidi, Anas (2004) Menekuk. Agama, Membangun Tabta. Jakarta: Desantara. Saringendiyanti, Etty. (1993) Penempatan Situs Upacara Masa Hindu-Budha: Sebuah Kajian Lingkungan Fisik Kabuyutan di Jawa Barat. Tesis S2. Arkeologi FSUI. 